\title{
Angiogenesis and Its Therapeutic Opportunities
}

\author{
So Young Yoo and Sang Mo Kwon \\ Laboratory for Vascular Medicine and Stem Cell Biology, Convergence Stem Cell Research Center, Medical Research Institute, \\ Pusan National University School of Medicine, Yangsan 626-870, Republic of Korea \\ Correspondence should be addressed to Sang Mo Kwon; smkwon323@pusan.ac.kr
}

Received 12 March 2013; Accepted 7 July 2013

Academic Editor: Grzegorz Szewczyk

Copyright (C) 2013 S. Y. Yoo and S. M. Kwon. This is an open access article distributed under the Creative Commons Attribution License, which permits unrestricted use, distribution, and reproduction in any medium, provided the original work is properly cited.

\begin{abstract}
Angiogenesis plays critical roles in human physiology that range from reproduction and fetal growth to wound healing and tissue repair. The sophisticated multistep process is tightly regulated in a spatial and temporal manner by "on-off switch signals" between angiogenic factors, extracellular matrix components, and endothelial cells. Uncontrolled angiogenesis may lead to several angiogenic disorders, including vascular insufficiency (myocardial or critical limb ischemia) and vascular overgrowth (hemangiomas, vascularized tumors, and retinopathies). Thus, numerous therapeutic opportunities can be envisaged through the successful understanding and subsequent manipulation of angiogenesis. Here, we review the clinical implications of angiogenesis and discuss pro- and antiangiogenic agents that offer potential therapy for cancer and other angiogenic diseases.
\end{abstract}

\section{Introduction}

The growth of new capillaries from existing blood vessels, which is called angiogenesis, is mediated by a complex multistep process comprising a series of cellular events that lead to neovascularization $[1,2]$. Angiogenesis plays a central role in various physiological processes within human body, not only during fetal development but also in tissue repair after surgery or trauma. Angiogenesis can be a hallmark of wound healing, the menstrual cycle, cancer, and various ischemic and inflammatory diseases [3-5]. The realization that tumor growth is associated with new blood vessels led us to investigate the chemical factors that mediate angiogenesis, broadened our knowledge of pathological processes, and thus opened new possibilities for the diagnosis and treatment of these diseases.

The pivotal process of angiogenesis can be simply described as multiple steps. First, angiogenic stimuli cause increased endothelial cell (EC) permeability and cellular proliferation, which continues as the new capillary sprout elongates [6]. Second, proteolysis of basement membrane matricellular components is a necessary process to promote the invasion of ECs into the stroma of the neighboring tissue [7], in which the cooperative activity of the plasminogen activator (PA) system and matrix metalloproteinases (MMPs) is required. Third, migrated ECs trigger lumen formation as the sprout forms a multicellular structure. Then, a new capillary channel is formed. Finally, the capillary is stabilized through the construction of basement membrane, adherent junctions, and ECs (Figure 1).

A number of molecules are involved in these complex angiogenic cascades. Their names and functions are described briefly in the next section and are listed in Table 1. These factors are commonly used as the targets in strategies to manipulate angiogenesis. The pathological disruption of angiogenesis can be caused by either vascular insufficiency (myocardial or critical limb ischemia) or vascular overgrowth (hemangiomas, tumors, and retinopathies) (Table 2). Thus, therapeutic benefits may be realized by manipulating angiogenesis.

\section{Angiogenic Factors and Regulation of Angiogenesis}

In recent decades, numerous studies focused on identifying angiogenesis stimulators, which led to the identification of several angiogenic factors. Angiogenic factors can be categorized as follows: (1) soluble growth factors such as acidic and basic fibroblast growth factor (aFGF and bFGF) 


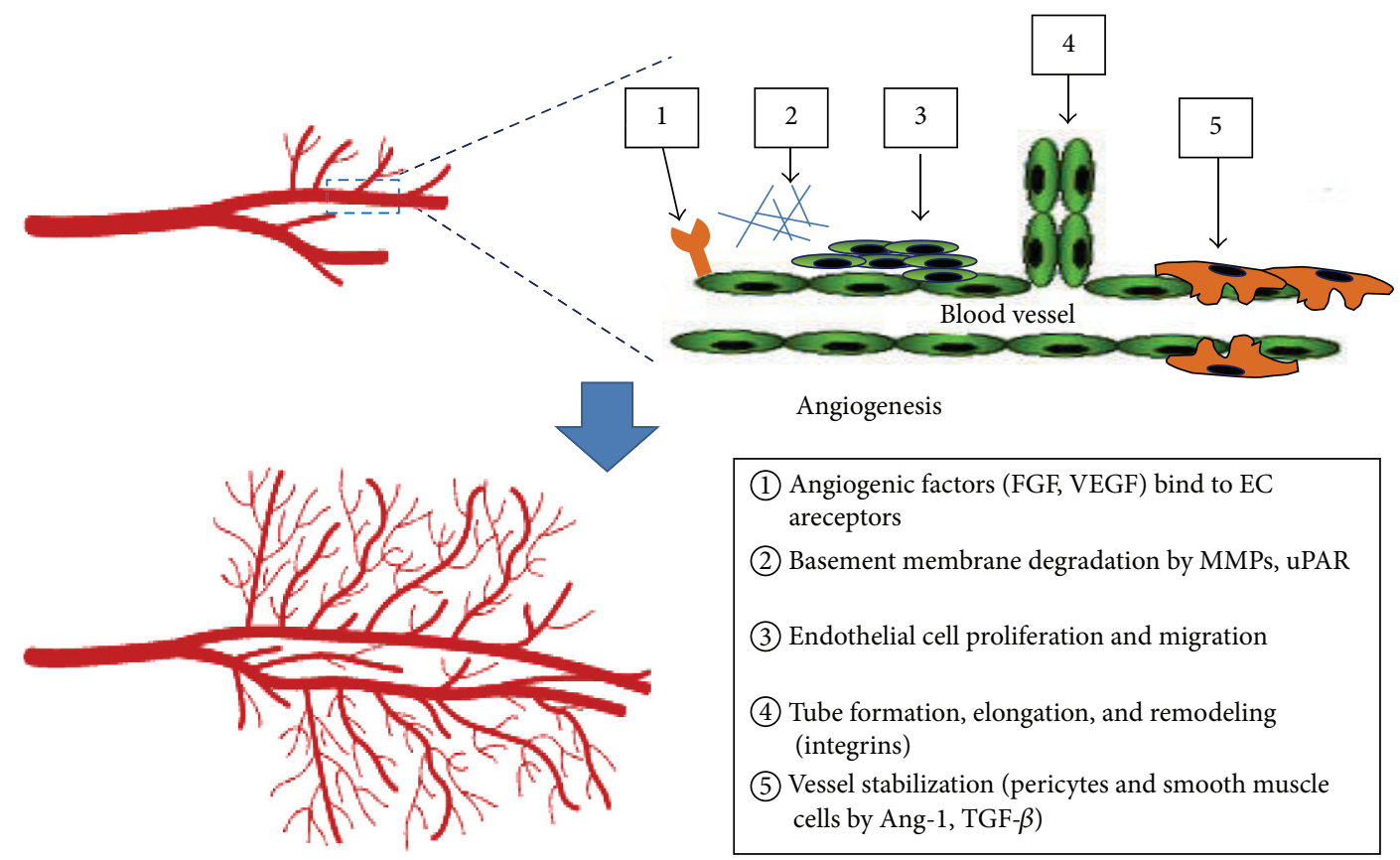

FIgURE 1: Processes in angiogenesis. (1) Angiogenic factors bind to their receptors on endothelial cells and activate the signal transduction pathways. (2) Matrix metalloproteinases are activated, and they degrade the extracellular matrix. (3) Endothelial cells migrate out of the preexisting capillary wall and proliferate. (4) Integrins are expressed by endothelial cells, facilitating their adhesion to the extracellular matrix and their migration for tube formation. (5) Angiopoietin 1 binds to Tie-2 receptors and stimulates pericyte recruitment and vessel stabilization.

and vascular endothelial growth factor (VEGF), which are associated with EC growth and differentiation [8-10]; (2) inhibiting factors that inhibit the proliferation and enhance the differentiation of ECs, such as transforming growth factor $\beta$ (TGF- $\beta$ ), angiogenin, and several low molecular weight substances [11-13]; and (3) extracellular matrix-bound cytokines that are released by proteolysis, which may contribute to the regulation of angiogenesis and include angiostatin, thrombospondin, and endostatin [14-18]. In addition, a number of microphages secreting bFGF, tumor necrosis factor (TNF), and VEGF were shown to be associated with tumor angiogenesis. Angiogenesis is governed by a balance between inducers and inhibitors [19]. It also can be regulated by EC proliferation, which is regulated or restrained by pericytes through the sequestration of potent mitogens in the extracellular matrix, changes in EC shape that reduce the sensitivity of the cells to growth factors, and certain endothelial integrins.

\section{Angiogenic Disorders}

The hypervascularity of tumors was first thought to be the inflammatory vasodilation of preexisting vessels in response to tumor metabolites and necrotic tumor products. It was also thought that tumor growth and metastasis depended on angiogenesis and that the tumor secreted the chemicals that shifted resting ECs into rapidly growing ECs. These ideas are not widely accepted yet. The concept of the role of angiogenesis in cancer and other diseases has now become clear.
3.1. Angiogenesis in Cancer. Most tumors (up to $2-3 \mathrm{~mm}^{3}$ ) persist in situ without neovascularization for months to years, but they become vascularized by "switches" in cells during the turnover to an angiogenic state when the tumor needs to keep growing. Cells in prevascular tumors may replicate as rapidly as those in expanding vascularized tumors; however, without the growth of new vessels, their growth is limited. A change in the local equilibrium between positive and negative angiogenic regulators of the growth of microvessels is involved in the switch to the angiogenic state $[20,21]$. Of the angiogenic inducers (Table 1), those that are most commonly found in tumors appear to be VEGF and bFGF. Their angiogenic activities are synergistic [22]. VEGF plays a critical role in vasculogenesis and angiogenesis during fetal development. In a knockout mouse model, VEGF or VEGF receptor (VEGFR) inactivation resulted in defects in vasculogenesis in the early stages of development and was embryonic lethal [23].

VEGF is overexpressed in tumor stromal cells as well as tumor cells of renal cancer [24], lung cancer [25], breast cancer [26], and ovarian cancer [27]. VEGF expression is regulated positively by oncogenes such as Ras [28] and negatively by tumor suppressors such as von Hippel-Lindau (VHL) [29]. VEGF binds to VEGFR1 or VEGFR2 on the EC surface. Most of the angiogenic effects of VEGF result from VEGFR2 activation. Hypoxia is a major stimulator of VEGF expression that results from hypoxia-inducible factor 1 (HIF-1) binding to a hypoxia response element (HRE) within the VEGF promoter. It is also stimulated by inflammatory mediators (interleukin 1 (IL1), TGF- $\beta$, and 
TABLE 1: Overview of the different angiogenic factors.

\begin{tabular}{|c|c|c|c|}
\hline Category & Names & Major functions & References \\
\hline Proteolytic enzymes & $\begin{array}{l}\text { (i) Matrix metalloproteinases (MMPs): } \\
\text { matrilysin (MMP-7), interstitial } \\
\text { collagenase (MMP-1), neutrophil } \\
\text { collagenase (MMP-8), collagenase-3 } \\
\text { (MMP-13), stromelysin-1 (MMP-3), } \\
\text { stromelysin-2 (MMP-10), stromelysin-3 } \\
\text { (MMP-11), metalloelastase (MMP-12), } \\
\text { MMP-19, enamelysin (MMP-20), } \\
\text { gelatinase A (MMP-2), gelatinase B } \\
\text { (MMP-9), MT1-MMP (MMP-14), } \\
\text { MT2-MMP (MMP-15), MT3-MMP } \\
\text { (MMP-16), MT4-MMP (MMP-17) } \\
\text { (ii) Plasminogen activators (PAs) }\end{array}$ & $\begin{array}{l}\text { MMPs; taking different substrates } \\
\text { according to MMPs; substrates can be } \\
\text { collagen, gelatin, laminin, fibronectin, } \\
\text { proteoglycans, and proMMPs }\end{array}$ & {$[67-69]$} \\
\hline Angiogenesis inducers & $\begin{array}{l}\text { Vascular endothelial growth factor family } \\
\text { (VEGF-A or VEGF, P1GF, VGGF-B, } \\
\text { VEGF-C, VEGF-D, orf virus VEGF or } \\
\text { VEGF-E), fibroblast growth factor family } \\
\text { (aFGF, bFGF, etc.), angiopoietin } 1 \\
\text { (Ang-1), transforming growth } \\
\text { factor-alpha/beta (TGF } \alpha / \beta) \text {, } \\
\text { platelet-derived growth factor (PDGF), } \\
\text { hepatocyte growth factor/scatter factor } \\
\text { (HGF/SF), tumor necrosis factor-alpha } \\
\text { (TNF } \alpha \text { ), interleukin-1/8, angiogenin, } \\
\text { ephrins, integrins } \alpha_{v} \beta_{3}, \alpha_{v} \beta_{5}, \alpha_{5} \beta_{1} \text {, } \\
\text { cyclooxygenase-2 (COX-2) }\end{array}$ & $\begin{array}{l}\text { (i) Induction of EC proliferation, } \\
\text { migration, and differentiation } \\
\text { (ii) TGF- } \beta \text { shows opposite effect in some } \\
\text { contexts }\end{array}$ & {$[8-10,70-79]$} \\
\hline Angiogenesis inhibitors & $\begin{array}{l}\text { Thrombospondin-1/2 (TSP-1/2), } \\
\text { angiostatin (plasminogen fragment), } \\
\text { endostatin (collagen XVIII fragment), } \\
\text { vasostatin (calreticulin fragment), } \\
\text { tumstatin, platelet factor-4 (PF4), } \\
\text { antiangiogenic antithrombin III, kringle } 5 \\
\text { (plasminogen fragment), prolactin } 16-\mathrm{kD} \\
\text { fragment, fragment of SPARC, } \\
\text { 2-methoxyestradiol, metalloproteinase } \\
\text { inhibitors (TIMPs), } \\
\text { interferon-alpha/beta/gamma (IFN } \\
\alpha / \beta / \gamma) \text {, interleukin-12 (IL-12), IP-10, } \\
\text { Ang-2 }\end{array}$ & $\begin{array}{l}\text { (i) Inhibit EC proliferation/migration } \\
\text { (ii) Induce EC apoptosis } \\
\text { (iii) TIMPs: inhibit MMP or uPA activity } \\
\text { (iv) Ang-2: inhibit blood vessels } \\
\text { maturation, antagonist of Ang-1 }\end{array}$ & {$[11-15,18,80-85]$} \\
\hline
\end{tabular}

prostaglandin E2 (PGE2)) or mechanical forces (shear stress and cell stretch). Increased PGE2 by cyclooxygenase-2 (COX2) induces VEGF expression and angiogenesis in tumor cells or tumor stromal cells [30]. FGF signaling may be through the recruitment of other growth factor signaling pathways. The simultaneous VEGF signaling through VEGFR1 was required in the bFGF-stimulated capillary organization. bFGF also initiates the transcription of hepatocyte growth factor (HGF) [31]. However, the upregulation of an angiogenic inducer is not sufficient for tumor angiogenesis. The downregulation of certain negative regulators or inhibitors (Table 1) for vessel growth may be required [21].

Tumor growth is augmented by the onset of neovascularization through a perfusion effect and a paracrine effect. The perfusion effect is more efficient at allowing nutrients and oxygen to enter and catabolites to exit in crowded tissues, and the paracrine effect results from the production of growth factors (e.g., bFGF, insulin-like growth factor (IGF), platelet-derived growth factor (PDGF), and granulocyte colony stimulating factor (GCSF)) by ECs or their release by macrophages and other host cells that are delivered to the tumor by blood vessels. Neovascularization gradually reduces a tumor's accessibility to chemotherapeutic drugs because tumors compress their blood supply. Antiangiogenic therapy in rodents showed increased delivery of chemotherapy agents to a tumor [32], which may be associated with lowered interstitial pressure and an unpacked mass of tumor cells.

3.2. Angiogenesis in Other Diseases. Either excessive or deficient angiogenesis can be classified as an angiogenic disease, which is an abnormal growth of microvessels (Table 2). Recent studies reported that the angiogenic protein VEGF is the chief mediator of ocular neovascularization, a major cause of blindness worldwide $[33,34]$. The upregulation of VEGF is 
TABLE 2: Clinical manipulation of angiogenesis.

\begin{tabular}{|c|c|c|c|}
\hline Therapeutic goal & Diseases & Definitions/symptoms & Reference \\
\hline \multirow{8}{*}{ Inhibition of angiogenesis } & Hemangiomas & $\begin{array}{l}\text { Benign and usually a self-involuting tumor (swelling or } \\
\text { growth) of the endothelial cells that line blood vessels } \\
\text { and is characterised by increased number of normal or } \\
\text { abnormal vessels filled with blood }\end{array}$ & {$[86]$} \\
\hline & Psoriasis & $\begin{array}{l}\text { Immune-mediated disease that affects the skin. The } \\
\text { immune system mistakes a normal skin cell for a } \\
\text { pathogen and sends out faulty signals that cause } \\
\text { overproduction of new skin cells }\end{array}$ & {$[37]$} \\
\hline & Kaposi’s sarcoma & Tumor caused by human herpesvirus 8 (HHV8) & {$[87]$} \\
\hline & Ocular neovascularization & $\begin{array}{l}\text { Abnormal or excessive formation of blood vessels in the } \\
\text { eye }\end{array}$ & {$[88]$} \\
\hline & Rheumatoid arthritis & $\begin{array}{l}\text { Inflammatory response of the capsule around the joints } \\
\text { (synovium), secondary to swelling (hyperplasia) of } \\
\text { synovial cells, excess synovial fluid, and the } \\
\text { development of fibrous tissue (pannus) in the synovium }\end{array}$ & {$[36]$} \\
\hline & Endometriosis & $\begin{array}{l}\text { A gynecological medical condition in which cells from } \\
\text { the lining of the uterus (endometrium) appear and } \\
\text { flourish outside the uterine cavity, most commonly on } \\
\text { the membrane which lines the abdominal cavity }\end{array}$ & [89] \\
\hline & Atherosclerosis & $\begin{array}{l}\text { Artery wall thickens caused largely by the accumulation } \\
\text { of macrophage white blood cells and promoted by } \\
\text { low-density lipoproteins (LDL, plasma proteins that } \\
\text { carry cholesterol and triglycerides) }\end{array}$ & [35] \\
\hline & $\begin{array}{l}\text { Tumor growth and } \\
\text { metastasis }\end{array}$ & $\begin{array}{l}\text { Tumor-associated neovascularization is involved in } \\
\text { tumor growth, invasion, and metastasis }\end{array}$ & {$[4]$} \\
\hline \multirow{3}{*}{ Stimulation of angiogenesis } & $\begin{array}{l}\text { Induction of collateral } \\
\text { vessel formation: } \\
\text { Myocardial ischemia, } \\
\text { Peripheral ischemia, } \\
\text { Cerebral ischemia }\end{array}$ & $\begin{array}{l}\text { After blood vessels blockage (occulsion), collateral } \\
\text { vessels can be developed to improve blood supply to the } \\
\text { area. }\end{array}$ & {$[90]$} \\
\hline & Wound healing & $\begin{array}{l}\text { Intricate process in which the skin (or another } \\
\text { organ-tissue) repairs itself after injury. Angiogenesis } \\
\text { occurs concurrently with fibroblast proliferation when } \\
\text { endothelial cells migrate to the area of the wound }\end{array}$ & \multirow[t]{2}{*}[91]{} \\
\hline & Reconstructive surgery & Surgery to restore the form and function of the body & \\
\hline
\end{tabular}

a response to the local hypoxia that is produced in tumors by vascular compression and ischemia. Thus, a similar process may cause the formation of collateral vessels in an ischemic heart or limb. Neovascularization in atherosclerotic plaques [35] may be mediated by the overexpression of VEGF and by local hypoxia, which contribute to the growth and rupture of plaques. The expression of both VEGF and bFGF is excessive in hemangiomas of infancy. In the case of rheumatoid arthritis, infiltrated macrophages, immune cells, or inflammatory cells produce excessive angiogenic factors that may mediate the ingrowth of a vascular pannus in a joint [36]. In psoriasis, hypervascular skin lesions over expressed the angiogenic polypeptide IL8 and under expressed the angiogenic inhibitor thrombospondin 1 (TSP-1) [37]. Peptic ulcers in animals appear to be deficient in microvessels in the ulcer bed. The oral administration of aFGF induced angiogenesis in the ulcer bed and accelerated the healing of ulcers in animals [38]. Bowel atresia, vascular malformations, hemangiomas, and unilateral facial atrophy are developmental disorders that are caused also by abnormal vascular development through defects in angiogenesis [39].

\section{Angiogenesis in Clinical Applications}

Abnormal angiogenesis is the major cause of numerous diseases; therefore, angiogenesis itself can be useful for diagnostic/prognostic applications and can be manipulated for further clinical applications. In the case of ischemic diseases, which develop because of deficient angiogenesis, an angiogenesis stimulator can be used to induce therapeutic angiogenesis. In the case of cancer, which has excessive angiogenesis, angiogenic inhibitors including antiangiogenic factors can be used to attenuate angiogenesis. The Food and Drug Administration (FDA) approved becaplermin (Regranex, recombinant human PDGF-BB) for diabetic foot ulcer disease in 1977, which was the first angiogenesisstimulating drug that was used as a therapeutic angiogenesis approach. For cancer therapeutics, the FDA approved 
bevacizumab (Avastin, humanized anti-VEGF monoclonal antibody), an angiogenesis inhibitor, to treat metastatic colorectal cancer in 2004 [40].

4.1. Diagnostic and Prognostic Applications. The quantitation of angiogenesis in a biopsy specimen may help predict the risk of metastasis or recurrence. The quantitation of microvessel density in histologic specimens of invasive breast cancer, for example, has provided an indication of the risk of metastasis [41]. A positive association between tumor angiogenesis and the risk of metastasis, tumor recurrence, or death has also been reported with regard to breast cancers and other types of tumors [42-44]. A high microvessel density may be a successful predictor of metastatic risk. An increased area of the vascular surface because of a high density may facilitate the escape of cancer cells into the circulation. An angiogenic cell that is shed from a primary tumor is more likely than a nonangiogenic cell to develop into a detectable metastasis.

The quantitation of angiogenic proteins in body fluids can be used to indirectly measure angiogenic activity. Higher concentrations of bFGF were found in the serum and urine of nearly $10 \%$ and more than $37 \%$ of cancer patients, respectively [45]. Concentrations of biologically active bFGF were abnormally high in the cerebrospinal fluid of children with brain tumors but not in children with hydrocephalus or malignant disease outside the central nervous system [46].

4.2. Therapeutic Angiogenesis. Therapeutic angiogenic drugs that accelerate the angiogenesis process are useful for treating diseases of deficient angiogenesis. In preclinical studies, orally administered bFGF was shown to stimulate angiogenesis and to accelerate the healing of duodenal ulcers in rats [38]. Phase I clinical trials were then prompted to evaluate this therapy in patients with gastric or duodenal ulcers that were refractory to conventional therapy [47]. Orally administrated bFGF was found to heal gastric ulcers that were caused by nonsteroidal anti-inflammatory drugs. Orally administrated aFGF induced angiogenesis in the ulcer bed and accelerated the healing of ulcers in animals [38].

A phase I clinical trial of therapeutic angiogenesis using bFGF protein in heparin-alginate slow-release microcapsules in 8 patients with symptomatic, severe coronary artery disease that was not amenable to complete revascularization by either percutaneous transluminal coronary angioplasty or coronary artery bypass grafting demonstrated the feasibility and safety of bFGF administration for coronary artery diseases [48]. These clinical studies suggest that angiogenic and other growth factors can heal gastrointestinal ulceration as well as coronary artery diseases. It is interesting to note that the antiulcer drug sucralfate (sucrose aluminum sulfate or Carafate) appears to act by protecting endogenous mucosal bFGF from degradation by acid.

Angiogenic agents can be used in ischemic heart disease as a therapeutic angiogenesis approach for cardiac tissue repair and regeneration $[49,50]$. The therapeutic goal of this condition is to stimulate angiogenesis to improve perfusion, deliver survival factors to sites of tissue repair, mobilize regenerative stem cell populations, and ultimately restore form and function to the tissue. Although more than 2,000 patients with heart disease have received some form of experimental angiogenic therapy $[51,52]$, currently there are no FDAapproved angiogenic drugs to treat ischemic cardiovascular disease. The first FDA-approved device to stimulate new blood vessel growth in diseased hearts is a laser that is used in a technique called direct myocardial revascularization (DMR) or transmyocardial revascularization (TMR).

\section{Antiangiogenic Therapies}

Many studies using ECs that were isolated from either capillaries or large vessels led to considerable insights into the molecular and cellular biology of angiogenesis and the discovery and evaluation of potential antiangiogenic compounds (Table 3). They were identified using classical angiogenesis assays such as the chick chorioallantoic membrane (CAM), rabbit cornea assay, sponge implant models, and matrigel plugs [53-57]. Recent research has focused on the specific effects of antiangiogenic compounds on individual angiogenic processes. In this section, we discuss their clinical applications as antiangiogenic therapies.

5.1. Interferon Alpha-2a to Treat Hemangiomas. Hemangiomas occur in 1 out of 100 neonates and in 1 out of 5 premature infants [58]. Most do not need treatment because these tumors grow rapidly in the first year of life (the proliferating phase), slow down during the next 5 years (the involuting phase), and gradually regress by the age of $10-$ 15 years (the involuted phase). However, about $10 \%$ of them may have serious tissue damage that includes interfering with a vital organ, obstructive airway, heart failure, or Kasabach-Merritt syndrome. Kasabach-Merritt syndrome, a platelet-trapping thrombocytopenic coagulopathy, and hepatic hemangiomas have a mortality rate of 30\%-50\%. Corticosteroid therapy worked for 30\% of hemangiomas [59]. Radiation, cyclophosphamide treatment, and embolization were also tried and showed favorable outcomes; however, sometimes they showed toxicity. Interferon alpha-2a (IFN $\alpha$ 2a) is an angiogenic agent that could be useful for treating these hemangiomas. It was successfully used in a 7-year-old child with pulmonary hemangiomas [60]. It was also found that therapy with IFN $\alpha-2 \mathrm{a}$ accelerated the tumor regression in 18 of 20 hemangioma patients [61]. IFN $\alpha$-2a suppresses the production of FGFs in human tumor cells, which could work for hemangiomas because bFGF is an angiogenic factor that is overexpressed in hemangiomas.

5.2. Ocular Neovascularization. Ophthalmology angiogenesis in the eye, an ocular neovascularization, includes agerelated macular degeneration (AMD), proliferative diabetic retinopathy (PDR), diabetic macular edema (DME), neovascular glaucoma, corneal neovascularization (trachoma), and pterygium. Inhibiting VEGF is presently an antiangiogenic therapy that is approved for ophthalmic conditions. Two currently approved antiangiogenic therapies for ophthalmic diseases are an anti-VEGF aptamer (pegaptanib, Macugen) and a Fab fragment of a monoclonal antibody directed against 
TABLE 3: Antiangiogenic compounds and their mechanism of action (adapted from references [2, 92-102]).

\begin{tabular}{|c|c|c|}
\hline $\begin{array}{l}\text { Inhibiting angiogenic } \\
\text { process }\end{array}$ & Antiangiogenic compounds & Mechanism of action \\
\hline \multirow{3}{*}{$\begin{array}{l}\text { Inhibitors of ECM } \\
\text { remodeling }\end{array}$} & $\begin{array}{l}\text { Batimastat, Marimastat, AG3340, Neovastat, } \\
\text { PEX, TIMP-1,2,3,4 }\end{array}$ & $\begin{array}{l}\text { MMP inhibitors, block endothelial and tumor } \\
\text { cell invasion }\end{array}$ \\
\hline & PAI-1,2, uPA Ab, uPAR Ab, Amiloride & uPA inhibitors, block ECM breakdown \\
\hline & $\begin{array}{l}\text { Minocycline, tetracyclines, cartilage-derived } \\
\text { TIMP }\end{array}$ & $\begin{array}{l}\text { Collagenase inhibitors, disrupt collagen } \\
\text { synthesis and deposition }\end{array}$ \\
\hline \multirow{2}{*}{$\begin{array}{l}\text { Inhibitors of adhesion } \\
\text { molecules }\end{array}$} & $\begin{array}{l}\alpha_{v} \beta_{3} \mathrm{Ab}: \mathrm{LM} 609 \text { and Vitaxin, RGD containing } \\
\text { peptides, } \alpha_{v} \beta_{5} \mathrm{Ab}\end{array}$ & Block EC adhesion, induce EC apoptosis \\
\hline & Benzodiazepine derivatives & Antagonist of $\alpha_{v} \beta_{3}$ \\
\hline \multirow{5}{*}{ Inhibitors of activated ECs } & $\begin{array}{l}\text { Endogenous inhibitors: endostatin, angiostatin, } \\
\text { aaAT }\end{array}$ & $\begin{array}{l}\text { Block EC proliferation, induce EC apoptosis, } \\
\text { inhibit angiogenic switch }\end{array}$ \\
\hline & $\begin{array}{l}\text { IFN- } \alpha \text {, IFN- } \gamma \text {, IL-12, nitric oxide synthase } \\
\text { inhibitors, TSP-1 }\end{array}$ & Block EC migration and/or proliferation \\
\hline & TNP-470, Combretastatin A-4 & Block EC proliferation \\
\hline & Thalidomide & Inhibits angiogenesis in vivo \\
\hline & Linomide & Inhibits EC migration \\
\hline \multirow{7}{*}{$\begin{array}{l}\text { Inhibitors of angiogenic } \\
\text { inducers or their receptors }\end{array}$} & IFN- $\alpha$, PF- 4 , prolactin fragment & $\begin{array}{l}\text { Inhibit bFGF, Inhibit bFGF-induced EC } \\
\text { proliferation }\end{array}$ \\
\hline & Suramin and analogues & $\begin{array}{l}\text { Bind to various growth factors including bFGF, } \\
\text { VEGF, PDGF, inhibit EC migration and } \\
\text { proliferation }\end{array}$ \\
\hline & $\begin{array}{l}\text { PPS, distamycin A analogues, bFGF Ab, } \\
\text { antisense-bFGF }\end{array}$ & Inhibit bFGF activity \\
\hline & Protamine & $\begin{array}{l}\text { Binds heparin, inhibits EC migration and } \\
\text { proliferation }\end{array}$ \\
\hline & $\begin{array}{l}\text { SU5416, soluble Flt-1, dominant-negative Flk-1, } \\
\text { VEGF receptor, ribozymes, VEGF Ab }\end{array}$ & Block VEGF activity \\
\hline & Aspirin, NS-398 & COX inhibitors \\
\hline & 6AT, 6A5BU, 7-DX & TP antagonists \\
\hline \multirow{3}{*}{$\begin{array}{l}\text { Inhibitors of EC } \\
\text { intracellular signaling }\end{array}$} & Genistein & $\begin{array}{l}\text { Tyrosine kinase inhibitor, blocks uPA, EC } \\
\text { migration and proliferation }\end{array}$ \\
\hline & Lavendustin A & Selective inhibitor of protein tyrosine kinase \\
\hline & Ang-2 & Inhibits Tie-2 \\
\hline
\end{tabular}

VEGF (ranibizumab, Lucentis). A photodynamic therapy called Visudyne (QLT Therapeutics/CIBA Vision) has shown effectiveness for treating macular degeneration and was the first FDA-approved blood vessel therapy for eye disease in $2004[62,63]$.

5.3. Rheumatoid Arthritis. Clinical trials of angiogenic inhibitors have not been performed yet in patients with arthritis; however, minocycline and TNP-470 (also known as AGM-470) have shown efficacy as potent inhibitors of the vascular pannus in experimental arthritis $[36,64]$.

5.4. Cancer. Angiogenesis plays a critical role in the growth and spread of cancer because a blood supply is necessary for tumor growth and metastases. Tumors secrete chemical signals that stimulate angiogenesis and thus stimulate nearby normal cells. Therefore, many natural or synthetic angiogenesis inhibitors, also called antiangiogenic agents, have been studied to prevent or slow the growth of cancer. These inhibitors can interfere with angiogenesis in various ways. Bevacizumab (Avastin) is a monoclonal antibody that specifically recognizes and binds to VEGF, which prevents VEGF from activating VEGFR [40]. In contrast, other angiogenesis inhibitors, including sorafenib and sunitinib, bind to receptors on the ECs or to other proteins in the downstream signaling pathways to block their activities [65].

Bevacizumab was FDA-approved to be used alone to treat glioblastoma and to be used in combination with other drugs to treat metastatic colorectal cancer, some nonsmall cell lung cancers, and metastatic renal cell cancer. Bevacizumab is the first approved angiogenesis inhibitor that was shown to slow tumor growth and, more importantly, to extend the lives of patients with some cancers. The other FDA-approved antiangiogenic drugs are sorafenib (Nexavar) for hepatocellular carcinoma and kidney cancer, sunitinib (Sutent) for kidney cancer and neuroendocrine tumors, pazopanib (Votrient) for kidney cancer and neuroendocrine tumors, and everolimus 
TABLE 4: Selected angiogenesis inhibitors in clinical trials.

\begin{tabular}{|c|c|c|c|c|}
\hline Inhibiting target & Drug & Sponsor & Clinical trials/mechanism & References \\
\hline \multirow{4}{*}{$\begin{array}{l}\text { Epidermal growth } \\
\text { factor receptor } \\
\text { (EGFR) }\end{array}$} & Gefitinib (Iressa) & AstraZeneca and Teva & $\begin{array}{l}\text { FDA-approved in } 2003 \text { for NSCLC/effective in } \\
\text { cancers with mutated and overactive EGFR }\end{array}$ & {$[103,104]$} \\
\hline & Lapatinib (Tykerb) & GSK & $\begin{array}{l}\text { FDA-approved in } 2007 \text { for breast cancer/dual } \\
\text { tyrosine kinase inhibitor which interrupts the } \\
\text { HER2/neu and epidermal growth factor receptor } \\
\text { (EGFR) pathways }\end{array}$ & [105] \\
\hline & Erlotinib (Tarceva) & $\begin{array}{c}\text { Genentech/OSI } \\
\text { pharmaceuticals/Roche }\end{array}$ & $\begin{array}{l}\text { FDA-approved in } 2005 / \text { used to treat nonsmall cell } \\
\text { lung cancer, pancreatic cancer, and several other } \\
\text { types of cancer }\end{array}$ & [106] \\
\hline & $\begin{array}{l}\text { Canertinib } \\
(\text { CI-1033) }\end{array}$ & Selleck Chemicals & $\begin{array}{l}\text { Phase II/irreversible tyrosine-kinase inhibitor } \\
\text { with activity against EGFR, HER-2, and ErbB- } 4\end{array}$ & {$[107]$} \\
\hline VEGFR & $\begin{array}{l}\text { Vatalanib }(\mathrm{PTK} 787 \\
\quad \text { or PTK/ZK) }\end{array}$ & $\begin{array}{l}\text { Bayer Schering and } \\
\quad \text { Novartis }\end{array}$ & $\begin{array}{l}\text { Phase III/it inhibits all known VEGF receptors, as } \\
\text { well as platelet-derived growth factor } \\
\text { receptor-beta and c-kit, but is most selective for } \\
\text { VEGFR-2 }\end{array}$ & [108] \\
\hline VEGFR-2 & IMC-1C11 & ImClone Systems & Phase I/chimerized monoclonal antibody & {$[109]$} \\
\hline VEGFR-3 & $\mathrm{mF} 4-31 \mathrm{Cl}$ & ImClone Systems & $\begin{array}{l}\text { Phase I/rat monoclonal antibody to murine } \\
\text { VEGFR-3, which potently antagonizes the } \\
\text { binding of VEGF-C to VEGFR-3 }\end{array}$ & {$[110]$} \\
\hline \multirow{4}{*}{$\begin{array}{l}\text { Multiple growth } \\
\text { factor receptors }\end{array}$} & Imatinib (Glivec) & Novartis & $\begin{array}{l}\text { FDA-approved in } 2001 / \text { competitive } \\
\text { tyrosine-kinase inhibitor used in the treatment of } \\
\text { multiple cancers, most notably Philadelphia } \\
\text { chromosome-positive }\left(\mathrm{Ph}^{+}\right) \text {chronic myelogenous } \\
\text { leukemia (CML) }\end{array}$ & {$[111]$} \\
\hline & Sunitinib (Sutent) & Pfizer & $\begin{array}{l}\text { FDA-approved in } 2006 \text { for renal cell carcinoma } \\
\text { (RCC) and imatinib-resistant gastrointestinal } \\
\text { stromal tumor (GIST)/the simultaneous } \\
\text { inhibition of receptors for platelet-derived growth } \\
\text { factor (PDGF-Rs) and vascular endothelial } \\
\text { growth factor receptors (VEGFRs) }\end{array}$ & {$[112]$} \\
\hline & $\begin{array}{l}\text { Sorafenib } \\
\text { (Nexavar) }\end{array}$ & $\begin{array}{l}\text { Bayer and Onyx } \\
\text { pharmaceuticals }\end{array}$ & $\begin{array}{l}\text { FDA-approved in 2005/a small molecular } \\
\text { inhibitor of several tyrosine protein kinases } \\
\text { (VEGFR and PDGFR) and Raf kinases (more } \\
\text { avidly C-Raf than B-Raf) }\end{array}$ & {$[113]$} \\
\hline & $\begin{array}{l}\text { Pazopanib } \\
\text { (Votrient) }\end{array}$ & GlaxoSmithKline & $\begin{array}{l}\text { FDA-approved in } 2009 \text { for advanced renal } \\
\text { cancer/multitargeted receptor tyrosine kinase } \\
\text { inhibitor of VEGFR-1, VEGFR-2, VEGFR-3, } \\
\text { PDGFR-a/ } \beta \text {, and c-kit }\end{array}$ & {$[114]$} \\
\hline VEGF & $\begin{array}{l}\text { Bevacizumab } \\
\text { (Avastin) }\end{array}$ & Genentech/Roche & $\begin{array}{l}\text { FDA-approved in } 2004 \text { for metastatic colorectal } \\
\text { cancer/humanized anti-VEGF mAb, licensed to } \\
\text { treat various cancers including colorectal, lung, } \\
\text { breast (outside the USA), glioblastoma (USA } \\
\text { only), kidney, and ovarian }\end{array}$ & {$[115,116]$} \\
\hline Integrin $\alpha_{V} \beta_{3}$ & Vitaxin & $\begin{array}{l}\text { Applied molecular } \\
\text { evolution }\end{array}$ & $\begin{array}{l}\text { Phase II as a treatment for colorectal } \\
\text { cancer/humanized monoclonal antibody against } \\
\text { the vascular integrin } \alpha_{V} \beta_{3}\end{array}$ & {$[117]$} \\
\hline
\end{tabular}

(Afinitor) for kidney cancer. Researchers are exploring the use of angiogenesis inhibitors in some clinical trials (Table 4).

5.5. Conventional Anticancer Therapy versus Antiangiogenic Therapy. Conventional anticancer therapy generally faces the problems of drug resistance and impaired drug delivery because of genomic instability and the tumor mass of cancers [66]. Tumor mass has an interstitium composed of a collagen-rich matrix between cancer cells and vascular cells. Anticancer drugs need to pass through the interstitium from blood vessels to reach the cancer cells. However, tumor mass has an interstitium with an abnormally high interstitial fluid pressure, which acts as a barrier to drug delivery. However, angiogenesis inhibitors inhibit the growth of blood vessels rather than tumor cells. In some cancers, angiogenesis inhibitors are most effective when they are combined with additional therapies, especially chemotherapy. It has been 
hypothesized that these drugs help normalize the blood vessels that supply the tumor, facilitating the delivery of other anticancer agents [32]. Angiogenesis inhibitor therapy may prevent tumor growth instead of killing tumors. Therefore, antiangiogenic therapy may require a long period for treatment.

\section{Concluding Remarks and Prospects}

Currently, chemotherapeutic drugs are being used to treat cancer as well as other diseases. Unfortunately, many compounds showed limited efficacy with impaired delivery, penetration, and selectivity for the tumor cells, thereby causing serious side effects and bystander effects. The activity of these compounds is mainly restricted by the drug resistance of tumor cells. Preclinical studies and clinical trials suggest that angiogenesis-based therapy may be useful in the future care of patients. In particular, antiangiogenic therapy is a unique approach to kill tumor cells because it does not directly target cancer cells; instead, it inhibits the growth of blood vessels. So far, antiangiogenic agents are not likely to result in bone marrow suppression, gastrointestinal symptoms, or hair loss. The approach to slow the growth of blood vessels may require several months to a year; thus, the administration of the agents at lower doses and longer uninterrupted periods than the usual doses and periods of conventional cytotoxic agents should be considered in the design of clinical trials. The development of resistance to angiogenic inhibitors has not been a big problem so far. Furthermore, a combination of antiangiogenic therapy and conventional therapy may be more effective than either therapy alone. Angiogenesis-based therapy may provide a novel, selective, safe, and reasonable treatment in future medicine.

\section{Conflict of Interests}

The authors declare that there is no conflict of interests.

\section{Acknowledgment}

This work was supported by Grants from the National Research Foundation funded by the Korean government (MEST: 2010-0020260, 20120618， 2012M3A9C6049720; MSIFP: 2013R1A1A3008484).

\section{References}

[1] J. Folkman, "Clinical applications of research on angiogenesis," The New England Journal of Medicine, vol. 333, no. 26, pp. 1757$1763,1995$.

[2] M. Klagsbrun and M. A. Moses, "Molecular angiogenesis," Chemistry and Biology, vol. 6, no. 8, pp. R217-R224, 1999.

[3] J. Folkman, "Angiogenesis in cancer, vascular, rheumatoid and other disease," Nature Medicine, vol. 1, no. 1, pp. 27-31, 1995.

[4] J. M. Pluda, "Tumor-associated angiogenesis: mechanisms, clinical implications, and therapeutic strategies," Seminars in Oncology, vol. 24, no. 2, pp. 203-218, 1997.
[5] C. G. Colpaert, P. B. Vermeulen, I. Benoy et al., "Inflammatory breast cancer shows angiogenesis with high endothelial proliferation rate and strong E-cadherin expression," British Journal of Cancer, vol. 88, no. 5, pp. 718-725, 2003.

[6] M. S. Pepper, "Role of the matrix metalloproteinase and plasminogen activator-plasmin systems in angiogenesis," Arteriosclerosis, Thrombosis, and Vascular Biology, vol. 21, no. 7, pp. 1104-1117, 2001.

[7] P. Mignatti and D. B. Rifkin, "Plasminogen activators and matrix metalloproteinases in angiogenesis," Enzyme and Protein, vol. 49, no. 1-3, pp. 117-137, 1996.

[8] W. H. Burgess and T. Maciag, "The heparin-binding (fibroblast) growth factor family of proteins," Annual Review of Biochemistry, vol. 58, pp. 575-602, 1989.

[9] G. Conn, M. L. Bayne, D. D. Soderman et al., "Amino acid and cDNA sequences of a vascular endothelial cell mitogen that is homologous to platelet-derived growth factor," Proceedings of the National Academy of Sciences of the United States of America, vol. 87, no. 7, pp. 2628-2632, 1990.

[10] A. Hoeben, B. Landuyt, M. S. Highley, H. Wildiers, A. T. van Oosterom, and E. A. De Bruijn, "Vascular endothelial growth factor and angiogenesis," Pharmacological Reviews, vol. 56, no. 4, pp. 549-580, 2004.

[11] M. A. Sovak, M. Arsura, G. Zanieski, K. T. Kavanagh, and G. E. Sonenshein, "The inhibitory effects of transforming growth factor $\beta 1$ on breast cancer cell proliferation are mediated through regulation of aberrant nuclear factor- $\kappa \mathrm{B} /$ Rel expression," Cell Growth and Differentiation, vol. 10, no. 8, pp. 537-544, 1999.

[12] A. B. Roberts and M. B. Sporn, "Regulation of endothelial cell growth, architecture, and matrix synthesis by TGF- $\beta$," American Review of Respiratory Disease, vol. 140, no. 4, pp. 1126-1128, 1989.

[13] J. Folkman and M. Klagsbrun, "Angiogenic factors," Science, vol. 235, no. 4787, pp. 442-447, 1987.

[14] K. Norrby, "Mast cells and angiogenesis: review article," APMIS, vol. 110, no. 5, pp. 355-371, 2002.

[15] M. S. O’Reilly, L. Holmgren, Y. Shing et al., "Angiostatin: a novel angiogenesis inhibitor that mediates the suppression of metastases by a Lewis lung carcinoma," Cell, vol. 79, no. 2, pp. 315-328, 1994.

[16] S. Gately, P. Twardowski, M. S. Stack et al., "Human prostate carcinoma cells express enzymatic activity that converts human plasminogen to the angiogenesis inhibitor, angiostatin," Cancer Research, vol. 56, no. 21, pp. 4887-4890, 1996.

[17] L. A. DiPietro and P. J. Polverini, "Angiogenic macrophages produce the angiogenic inhibitor thrombospondin 1," American Journal of Pathology, vol. 143, no. 3, pp. 678-684, 1993.

[18] M. S. O’Reilly, T. Boehm, Y. Shing et al., "Endostatin: an endogenous inhibitor of angiogenesis and tumor growth," Cell, vol. 88, no. 2, pp. 277-285, 1997.

[19] M. L. Iruela-Arispe and H. F. Dvorak, "Angiogenesis: a dynamic balance of stimulators and inhibitors," Thrombosis and Haemostasis, vol. 78, no. 1, pp. 672-677, 1997.

[20] L. Holmgren, M. S. O’Reilly, and J. Folkman, "Dormancy of micrometastases: balanced proliferation and apoptosis in the presence of angiogenesis suppression," Nature Medicine, vol. 1, no. 2, pp. 149-153, 1995.

[21] K. M. Dameron, O. V. Volpert, M. A. Tainsky, and N. Bouck, "Control of angiogenesis in fibroblasts by p53 regulation of thrombospondin-1," Science, vol. 265, no. 5178, pp. 1582-1584, 1994. 
[22] M. S. Pepper, N. Ferrara, L. Orci, and R. Montesano, "Potent synergism between vascular endothelial growth factor and basic fibroblast growth factor in the induction of angiogenesis in vitro," Biochemical and Biophysical Research Communications, vol. 189, no. 2, pp. 824-831, 1992.

[23] N. Ferrara, K. Carver-Moore, H. Chen et al., "Heterozygous embryonic lethality induced by targeted inactivation of the VEGF gene," Nature, vol. 380, no. 6573, pp. 439-442, 1996.

[24] M. Tomisawa, T. Tokunaga, Y. Oshika et al., "Expression pattern of vascular endothelial growth factor isoform is closely correlated with tumour stage and vascularisation in renal cell carcinoma," European Journal of Cancer, vol. 35, no. 1, pp. 133137, 1999.

[25] M. Volm, R. Koomägi, and J. Mattern, "Prognostic value of vascular endothelial growth factor and its receptor Flt-1 in squamous cell lung cancer," International Journal of Cancer, vol. 74, no. 1, pp. 64-68, 1997.

[26] H. Yoshiji, D. E. Gomez, M. Shibuya, and U. P. Thorgeirsson, "Expression of vascular endothelial growth factor, its receptor, and other angiogenic factors in human breast cancer," Cancer Research, vol. 56, no. 9, pp. 2013-2016, 1996.

[27] H. M. Sowter, A. N. Corps, A. L. Evans, D. E. Clark, D. S. Charnock-Jones, and S. K. Smith, "Expression and localization of the vascular endothelial growth factor family in ovarian epithelial tumors," Laboratory Investigation, vol. 77, no. 6, pp. 607-617, 1997.

[28] F. Okada, J. W. Rak, B. S. Croix et al., "Impact of oncogenes in tumor angiogenesis: mutant K-ras up-regulation of vascular endothelial growth factor/vascular permeability factor is necessary, but not sufficient for tumorigenicity of human colorectal carcinoma cells," Proceedings of the National Academy of Sciences of the United States of America, vol. 95, no. 7, pp. 3609-3614, 1998.

[29] O. Iliopoulos, A. P. Levy, C. Jiang, W. G. Kaelin Jr., and M. A. Goldberg, "Negative regulation of hypoxia-inducible genes by the von Hippel-Lindau protein," Proceedings of the National Academy of Sciences of the United States of America, vol. 93, no. 20, pp. 10595-10599, 1996.

[30] H. Seno, M. Oshima, T.-O. Ishikawa et al., "Cyclooxygenase 2and prostaglandin E2 receptor EP2-dependent angiogenesis in Apc $\Delta 716$ mouse intestinal polyps," Cancer Research, vol. 62, no. 2, pp. 506-511, 2002.

[31] M. Onimaru, Y. Yonemitsu, M. Tanii et al., "Fibroblast growth factor-2 gene transfer can stimulate hepatocyte growth factor expression irrespective of hypoxia-mediated downregulation in ischemic limbs," Circulation Research, vol. 91, no. 10, pp. 923930, 2002.

[32] B. A. Teicher, S. A. Holden, G. Ara et al., "Potentiation of cytotoxic cancer therapies by TNP-470 alone and with other anti-angiogenic agents," International Journal of Cancer, vol. 57, no. 6, pp. 920-925, 1994.

[33] J. W. Miller, A. P. Adamis, D. T. Shima et al., "Vascular endothelial growth factor/vascular permeability factor is temporally and spatially correlated with ocular angiogenesis in a primate model," American Journal of Pathology, vol. 145, no. 3, pp. 574584, 1994.

[34] L. P. Aiello, R. L. Avery, P. G. Arrigg et al., "Vascular endothelial growth factor in ocular fluid of patients with diabetic retinopathy and other retinal disorders," The New England Journal of Medicine, vol. 331, no. 22, pp. 1480-1487, 1994.
[35] E. R. O’Brien, M. R. Garvin, R. Dev et al., "Angiogenesis in human coronary atherosclerotic plaques," American Journal of Pathology, vol. 145, no. 4, pp. 883-894, 1994.

[36] D. J. Peacock, M. L. Banquerigo, and E. Brahn, "Angiogenesis inhibition suppresses collagen arthritis," Journal of Experimental Medicine, vol. 175, no. 4, pp. 1135-1138, 1992.

[37] B. J. Nickoloff, R. S. Mitra, J. Varani, V. M. Dixit, and P. J. Polverini, "Aberrant production of interleukin-8 and thrombospondin-1 by psoriatic keratinocytes mediates angiogenesis," American Journal of Pathology, vol. 144, no. 4, pp. 820 828, 1994.

[38] J. Folkman, S. Szabo, M. Stovroff, P. McNeil, W. Li, and Y. Shing, "Duodenal ulcer: discovery of a new mechanism and development of angiogenic therapy that accelerates healing," Annals of Surgery, vol. 214, no. 4, pp. 414-427, 1991.

[39] B. Gontijo, L. B. Pereira, and C. M. R. Silva, "Vascular malformations," Anais Brasileiros de Dermatologia, vol. 79, no. 1, pp. $7-25,2004$.

[40] T. Shih and C. Lindley, "Bevacizumab: an angiogenesis inhibitor for the treatment of solid malignancies," Clinical Therapeutics, vol. 28, no. 11, pp. 1779-1802, 2006.

[41] N. Weidner, J. P. Semple, W. R. Welch, and J. Folkman, “Tumor angiogenesis and metastasis-correlation in invasive breast carcinoma," The New England Journal of Medicine, vol. 324, no. 1, pp. 1-8, 1991.

[42] R. Vang, F. A. Tavassoli, A. Shaaban, and C. S. Foster, "Risk for subsequent development of breast cancer," American Journal of Surgical Pathology, vol. 27, no. 2, pp. 268-274, 2003.

[43] J. P. Dales, S. Garcia, S. Carpentier et al., "Long-term prognostic significance of neoangiogenesis in breast carcinomas: comparison of Tie-2/Tek, CD105, and CD31 immunocytochemical expression," Human Pathology, vol. 35, no. 2, pp. 176-183, 2004.

[44] K. Sfiridaki, C. A. Pappa, G. Tsirakis et al., "Angiogenesisrelated cytokines, RANKL, and osteoprotegerin in multiple myeloma patients in relation to clinical features and response to treatment," Mediators of Inflammation, vol. 2011, Article ID 867576, 7 pages, 2011.

[45] M. Nguyen, H. Watanabe, A. E. Budson, J. P. Richie, D. F. Hayes, and J. Folkman, "Elevated levels of an angiogenic peptide, basic fibroblast growth factor, in the urine of patients with a wide spectrum of cancers," Journal of the National Cancer Institute, vol. 86, no. 5, pp. 356-361, 1994.

[46] V. W. Li, R. D. Folkerth, H. Watanabe et al., "Microvessel count and cerebrospinal fluid basic fibroblast growth factor in children with brain tumours," The Lancet, vol. 344, no. 8915, pp. 82-86, 1994.

[47] M. A. Hull, D. J. E. Cullen, N. Hudson, and C. J. Hawkey, "Basic fibroblast growth factor treatment for non-steroidal antiinflammatory drug associated gastric ulceration," Gut, vol. 37, no. 5, pp. 610-612, 1995.

[48] F. W. Sellke, R. J. Laham, E. R. Edelman, J. D. Pearlman, and M. Simons, "Therapeutic angiogenesis with basic fibroblast growth factor: technique and early results," Annals of Thoracic Surgery, vol. 65, no. 6, pp. 1540-1544, 1998.

[49] W. W. Li, K. E. Talcott, A. W. Zhai, E. A. Kruger, and V. W. $\mathrm{Li}$, "The role of therapeutic angiogenesis in tissue repair and regeneration," Advances in Skin \& Wound Care, vol. 18, no. 9, pp. 491-502, 2005.

[50] S.-W. Lee, J.-Y. Won, H.-Y. Lee et al., "Angiopoietin-1 protects heart against ischemia/reperfusion injury through VE-cadherin dephosphorylation and myocardiac integrin- $\beta 1 /$ ERK/caspase- 9 
phosphorylation cascade," Molecular Medicine, vol. 17, no. 9-10, pp. 1095-1106, 2011.

[51] P. R. Vale, D. W. Losordo, J. F. Symes, and J. M. Isner, "Growth factors for therapeutic angiogenesis in cardiovascular diseases," Revista Espanola de Cardiologia, vol. 54, no. 10, pp. 1210-1224, 2001.

[52] M. Simons, R. O. Bonow, N. A. Chronos et al., "Clinical trials in coronary angiogenesis: issues, problems, consensus: an expert panel summary," Circulation, vol. 102, no. 11, pp. E73-E86, 2000.

[53] R. Auerbach, W. Auerbach, and I. Polakowski, "Assays for angiogenesis: a review," Pharmacology and Therapeutics, vol. 51, no. 1, pp. 1-11, 1991.

[54] R. K. Jain, K. Schlenger, M. Höckel, and F. Yuan, "Quantitative angiogenesis assays: progress and problems," Nature Medicine, vol. 3, no. 11, pp. 1203-1208, 1997.

[55] G. W. Cockerill, J. R. Gamble, and M. A. Vadas, "Angiogenesis: models and modulators," International Review of Cytology, vol. 159, pp. 113-160, 1995.

[56] K. Norrby, "In vivo models of angiogenesis," Journal of Cellular and Molecular Medicine, vol. 10, no. 3, pp. 1-25, 2006.

[57] D. Ribatti and A. Vacca, "Models for studying angiogenesis in vivo," International Journal of Biological Markers, vol. 14, no. 4, pp. 207-213, 1999.

[58] D. V. Dado, "Vascular birthmarks, hemangiomas and malformations," Annals of Plastic Surgery, vol. 23, no. 1, 1989.

[59] E. Pope, B. R. Krafchik, C. Macarthur et al., "Oral versus highdose pulse corticosteroids for problematic infantile hemangiomas: a randomized, controlled trial," Pediatrics, vol. 119, no. 6, pp. e1239-e1247, 2007.

[60] C. W. White, H. M. Sondheimer, E. C. Crouch, H. Wilson, and L. L. Fan, "Treatment of pulmonary hemangiomatosis with recombinant interferon alfa-2a," The New England Journal of Medicine, vol. 320, no. 18, pp. 1197-1200, 1989.

[61] R. A. B. Ezekowitz, J. B. Mulliken, and J. Folkman, "Interferon alfa-2a therapy for life-threatening hemangiomas of infancy," The New England Journal of Medicine, vol. 326, no. 22, pp. 14561463, 1992.

[62] C. M. Andreoli and J. W. Miller, "Anti-vascular endothelial growth factor therapy for ocular neovascular disease," Current Opinion in Ophthalmology, vol. 18, no. 6, pp. 502-508, 2007.

[63] R. D. Jager, W. F. Mieler, and J. W. Miller, "Age-related macular degeneration," The New England Journal of Medicine, vol. 358, no. 24, pp. 2544-2617, 2008.

[64] H. E. Paulus, "Minocycline treatment of rheumatoid arthritis," Annals of Internal Medicine, vol. 122, no. 2, pp. 147-148, 1995.

[65] K. J. Gotink and H. M. W. Verheul, "Anti-angiogenic tyrosine kinase inhibitors: what is their mechanism of action?" Angiogenesis, vol. 13, no. 1, pp. 1-14, 2010.

[66] R. K. Jain, "Barriers to drug delivery in solid tumors," Scientific American, vol. 271, no. 1, pp. 58-65, 1994.

[67] J. Westermarck and V.-M. Kähäri, "Regulation of matrix metalloproteinase expression in tumor invasion," FASEB Journal, vol. 13, no. 8, pp. 781-792, 1999.

[68] H. Nagase, "Activation mechanisms of matrix metalloproteinases," Biological Chemistry, vol. 378, no. 3-4, pp. 151-160, 1997.

[69] V.-M. Kähäri and U. Saarialho-Kere, "Matrix metalloproteinases and their inhibitors in tumour growth and invasion," Annals of Medicine, vol. 31, no. 1, pp. 34-45, 1999.
[70] N. Ferrara and H. P. Gerber, "Vascular endothelial growth factor molecular and biological aspects," in Advances in Organ Biology, E. E. Bittar, Ed., pp. 25-57, Elsevier, London, UK, 1999.

[71] F. Bussolino, A. Albini, G. Camussi et al., "Role of soluble mediators in angiogenesis," European Journal of Cancer A, vol. 32, no. 14, pp. 2401-2412, 1996.

[72] C.-H. Heldin and B. Westermark, "Mechanism of action and in vivo role of platelet-derived growth factor," Physiological Reviews, vol. 79, no. 4, pp. 1283-1316, 1999.

[73] J. R. Jackson, M. P. Seed, C. H. Kircher, D. A. Willoughby, and J. D. Winkler, "The codependence of angiogenesis and chronic inflammation," FASEB Journal, vol. 11, no. 6, pp. 457-465, 1997.

[74] M. S. Pepper, "Transforming growth factor-beta: vasculogenesis, angiogenesis, and vessel wall integrity," Cytokine and Growth Factor Reviews, vol. 8, no. 1, pp. 21-43, 1997.

[75] E. M. Rosen, K. Lamszus, J. Laterra, P. J. Polverini, J. S. Rubin, and I. D. Goldberg, "HGF/SF in angiogenesis," CIBA Foundation Symposia, no. 212, pp. 215-226, 1997.

[76] D. A. Arenberg, P. J. Polverini, S. L. Kunkel et al., "The role of CXC chemokines in the regulation of angiogenesis in nonsmall cell lung cancer," Journal of Leukocyte Biology, vol. 62, no. 5, pp. 554-562, 1997.

[77] T. O. Daniel, H. Liu, J. D. Morrow, B. C. Crews, and L. J. Marnett, "Thromboxane A2 is a mediator of cyclooxygenase2-dependent endothelial migration and angiogenesis," Cancer Research, vol. 59, no. 18, pp. 4574-4577, 1999.

[78] J. Badet, "Angiogenin, a potent mediator of angiogenesis biological, biochemical and structural properties," Pathologie Biologie, vol. 47, no. 4, pp. 345-351, 1999.

[79] A. J. Hayes, W.-Q. Huang, J. Mallah, D. Yang, M. E. Lippman, and L.-Y. Li, "Angiopoietin-1 and its receptor tie-2 participate in the regulation of capillary-like tubule formation and survival of endothelial cells," Microvascular Research, vol. 58, no. 3, pp. 224-237, 1999.

[80] B. B. Moore, M. P. Keane, C. L. Addison, D. A. Arenberg, and R. M. Strieter, "CXC chemokine modulation of angiogenesis: the importance of balance between angiogenic and angiostatic members of the family," Journal of Investigative Medicine, vol. 46, no. 4, pp. 113-120, 1998.

[81] I. Struman, F. Bentzien, H. Lee et al., "Opposing actions of intact and N-terminal fragments of the human prolactin/growth hormone family members on angiogenesis: an efficient mechanism for the regulation of angiogenesis," Proceedings of the National Academy of Sciences of the United States of America, vol. 96, no. 4, pp. 1246-1251, 1999.

[82] C. P. N. Dinney, D. R. Bielenberg, P. Perrotte et al., "Inhibition of basic fibroblast growth factor expression, angiogenesis, and growth of human bladder carcinoma in mice by systemic interferon- $\alpha$ administration," Cancer Research, vol. 58, no. 4, pp. 808-814, 1998.

[83] N. Sato, H. Nariuchi, N. Tsuruoka et al., "Actions of TNF and IFN-gamma on angiogenesis in vitro," Journal of Investigative Dermatology, vol. 95, no. 6, supplement, pp. 85S-89S, 1990.

[84] C. Sgadari, A. L. Angiolillo, and G. Tosato, "Inhibition of angiogenesis by interleukin-12 is mediated by the interferoninducible protein 10," Blood, vol. 87, no. 9, pp. 3877-3882, 1996.

[85] D. E. Gomez, D. F. Alonso, H. Yoshiji, and U. P. Thorgeirsson, "Tissue inhibitors of metalloproteinases: structure, regulation and biological functions," European Journal of Cell Biology, vol. 74, no. 2, pp. 111-122, 1997. 
[86] A. N. Haggstrom, B. A. Drolet, E. Baselga et al., "Prospective study of infantile hemangiomas: clinical characteristics predicting complications and treatment," Pediatrics, vol. 118, no. 3, pp. 882-887, 2006.

[87] K. Kaposi, "Idiopathisches multiples Pigmentsarkom der Haut," Archiv für Dermatologie und Syphilis, vol. 4, no. 2, pp. 265-273, 1872.

[88] K. A. Neely and T. W. Gardner, "Ucular neovascularization: clarifying complex interactions," American Journal of Pathology, vol. 153, no. 3, pp. 665-670, 1998.

[89] C. L. Pearce, C. Templeman, M. A. Rossing et al., "Association between endometriosis and risk of histological subtypes of ovarian cancer: a pooled analysis of case-control studies," The Lancet Oncology, vol. 13, no. 4, pp. 385-394, 2012.

[90] M. Fernandez, F. Vizzutti, J. C. Garcia-Pagan, J. Rodes, and J. Bosch, "Anti-VEGF receptor- 2 monoclonal antibody prevents portal-systemic collateral vessel formation in portal hypertensive mice," Gastroenterology, vol. 126, no. 3, pp. 886-894, 2004.

[91] P. Martin, "Wound healing-aiming for perfect skin regeneration," Science, vol. 276, no. 5309, pp. 75-81, 1997.

[92] S. Liekens, E. de Clercq, and J. Neyts, "Angiogenesis: regulators and clinical applications," Biochemical Pharmacology, vol. 61, no. 3, pp. 253-270, 2001.

[93] G. Gasparini, “The rationale and future potential of angiogenesis inhibitors in neoplasia," Drugs, vol. 58, no. 1, pp. 17-38, 1999.

[94] V. Brower, "Tumor angiogenesis-new drugs on the block," Nature Biotechnology, vol. 17, no. 10, pp. 963-968, 1999.

[95] J. Balzarini, A. E. Gamboa, R. Esnouf et al., "7-Deazaxanthine, a novel prototype inhibitor of thymidine phosphorylase," FEBS Letters, vol. 438, no. 1-2, pp. 91-95, 1998.

[96] V. Cea, C. Sala, and C. Verpelli, "Antiangiogenic therapy for glioma," Journal of Signal Transduction, vol. 2012, Article ID 483040, 15 pages, 2012.

[97] H.-C. Wu, C.-T. Huang, and D.-K. Chang, "Anti-angiogenic therapeutic drugs for treatment of human cancer," Journal of Cancer Molecules, vol. 4, no. 2, pp. 37-45, 2008.

[98] H. G. Augustin, "Antiangiogenic tumour therapy: will it work?" Trends in Pharmacological Sciences, vol. 19, no. 6, pp. 216-222, 1998.

[99] T.-P. D. Fan, R. Jaggar, and R. Bicknell, "Controlling the vasculature: angiogenesis, anti-angiogenesis and vascular targeting of gene therapy," Trends in Pharmacological Sciences, vol. 16, no. 2, pp. 57-66, 1995.

[100] J. M. Hamby and H. D. H. Showalter, "Small molecule inhibitors of tumor-promoted angiogenesis, including protein tyrosine kinase inhibitors," Pharmacology and Therapeutics, vol. 82, no. 2-3, pp. 169-193, 1999.

[101] S. J. Shiff and B. Rigas, "Aspirin for cancer," Nature Medicine, vol. 5, no. 12, pp. 1348-1349, 1999.

[102] F. Parmeggiani, C. Campa, C. Costagliola et al., "Inflammatory mediators and angiogenic factors in choroidal neovascularization: pathogenetic interactions and therapeutic implications," Mediators of Inflammation, vol. 2010, Article ID 546826, 14 pages, 2010.

[103] W. Pao, V. Miller, M. Zakowski et al., "EGF receptor gene mutations are common in lung cancers from "never smokers" and are associated with sensitivity of tumors to gefitinib and erlotinib," Proceedings of the National Academy of Sciences of the United States of America, vol. 101, no. 36, pp. 13306-13311, 2004.

[104] M. H. Cohen, G. A. Williams, R. Sridhara, G. Chen, and R. Pazdur, "FDA drug approval summary: gefitinib (ZD1839) (Iressa®) tablets," Oncologist, vol. 8, no. 4, pp. 303-306, 2003.
[105] B. Moy, P. Kirkpatrick, S. Kar, and P. Goss, "Lapatinib," Nature Reviews Drug Discovery, vol. 6, no. 6, pp. 431-432, 2007.

[106] M. H. Cohen, J. R. Johnson, Y.-F. Chen, R. Sridhara, and R. Pazdur, "FDA drug approval summary: erlotinib (Tarceva®) tablets," Oncologist, vol. 10, no. 7, pp. 461-466, 2005.

[107] P. A. Jänne, J. Von Pawel, R. B. Cohen et al., "Multicenter, randomized, phase II trial of CI-1033, an irreversible pan-ERBB inhibitor, for previously treated advanced non-small-cell lung cancer," Journal of Clinical Oncology, vol. 25, no. 25, pp. 39363944, 2007.

[108] M. Los, J. M. L. Roodhart, and E. E. Voest, "Target practice: lessons from phase III trials with bevacizumab and vatalanib in the treatment of advanced colorectal cancer," Oncologist, vol. 12, no. 4, pp. 443-450, 2007.

[109] J. A. Posey, T. C. Ng, B. Yang et al., "A phase I study of antikinase insert domain-containing receptor antibody, IMC-1C11, in patients with liver metastases from colorectal carcinoma," Clinical Cancer Research, vol. 9, no. 4, pp. 1323-1332, 2003.

[110] B. Pytowski, J. Goldman, K. Persaud et al., "Complete and specific inhibition of adult lymphatic regeneration by a novel VEGFR-3 neutralizing antibody," Journal of the National Cancer Institute, vol. 97, no. 1, pp. 14-21, 2005.

[111] M. Habeck, "FDA licences imatinib mesylate for CML," The Lancet Oncology, vol. 3, no. 1, p. 6, 2002.

[112] E. P. Rock, V. Goodman, J. X. Jiang et al., "Food and Drug Administration drug approval summary: sunitinib malate for the treatment of gastrointestinal stromal tumor and advanced renal cell carcinoma," Oncologist, vol. 12, no. 1, pp. 107-113, 2007.

[113] L. Lang, "FDA approves sorafenib for patients with inoperable liver cancer," Gastroenterology, vol. 134, no. 2, p. 379, 2008.

[114] G. Sonpavde, T. E. Hutson, and C. N. Sternberg, "Pazopanib, a potent orally administered small-molecule multitargeted tyrosine kinase inhibitor for renal cell carcinoma," Expert Opinion on Investigational Drugs, vol. 17, no. 2, pp. 253-261, 2008.

[115] S. Sleijfer, I. Ray-Coquard, Z. Papai et al., "Pazopanib, a multikinase angiogenesis inhibitor, in patients with relapsed or refractory advanced soft tissue sarcoma: a phase II study from the European organisation for research and treatment of cancersoft tissue and bone sarcoma group (EORTC Study 62043)," Journal of Clinical Oncology, vol. 27, no. 19, pp. 3126-3132, 2009.

[116] A. Sandler, R. Herbst, P. Bunn et al., "Combining targeted agents: blocking the epidermal growth factor and vascular endothelial growth factor pathways," Clinical Cancer Research, vol. 12, no. 14, pp. 4421s-4425s, 2006.

[117] D. G. McNeel, J. Eickhoff, F. T. Lee et al., "Phase I trial of a monoclonal antibody specific for $\alpha \mathrm{v} \beta 3$ integrin (MEDI-522) in patients with advanced malignancies, including an assessment of effect on tumor perfusion," Clinical Cancer Research, vol. 11, no. 21, pp. 7851-7860, 2005. 


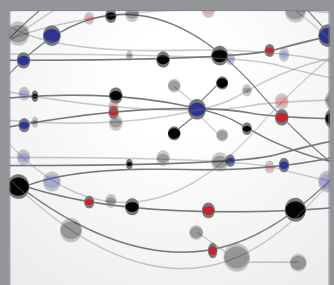

The Scientific World Journal
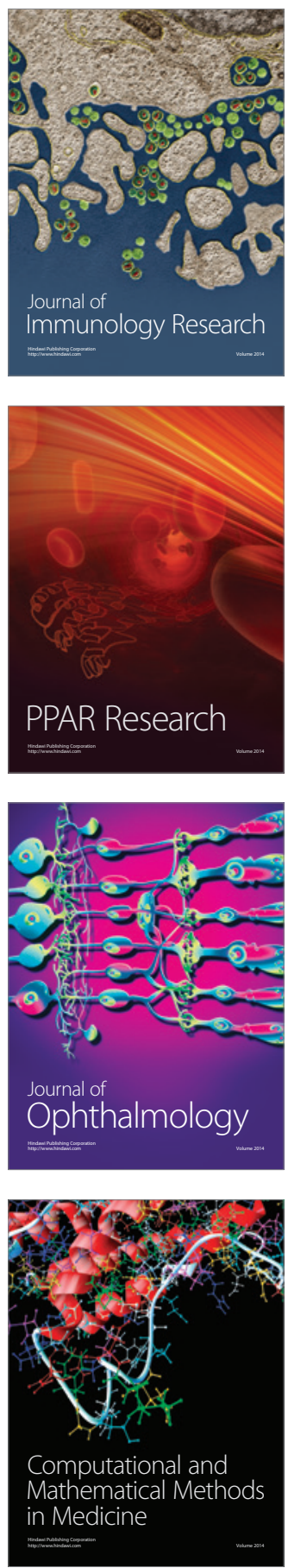

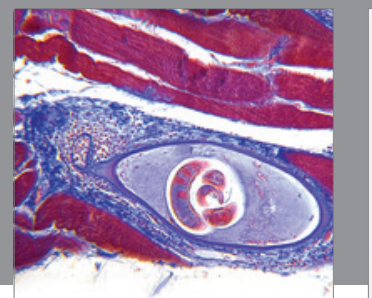

Gastroenterology

Research and Practice
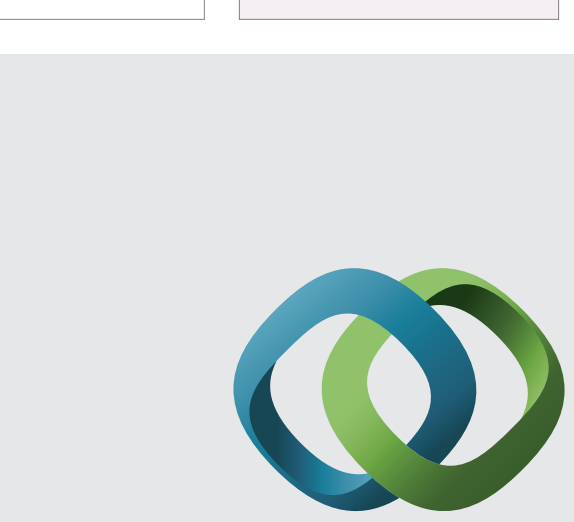

\section{Hindawi}

Submit your manuscripts at

http://www.hindawi.com
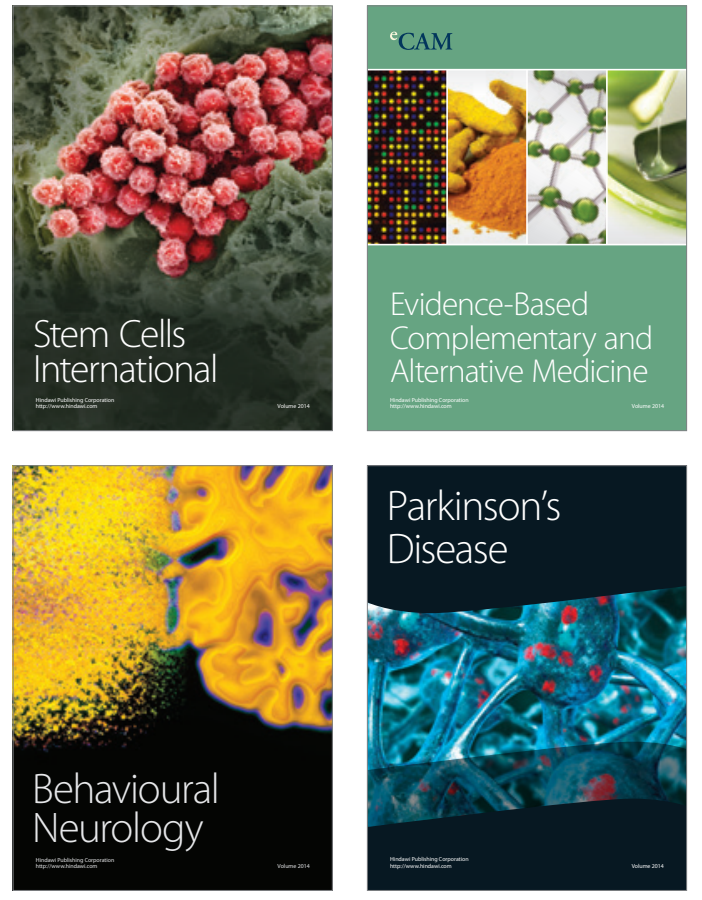
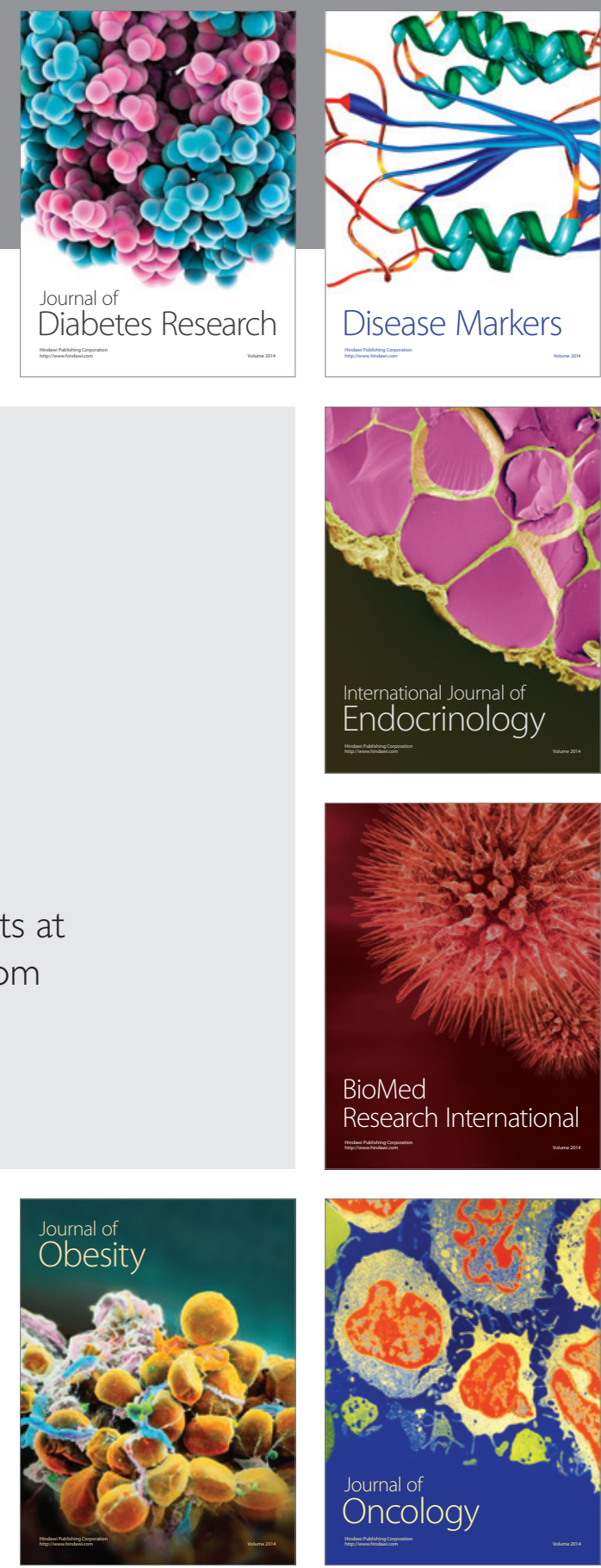

Disease Markers
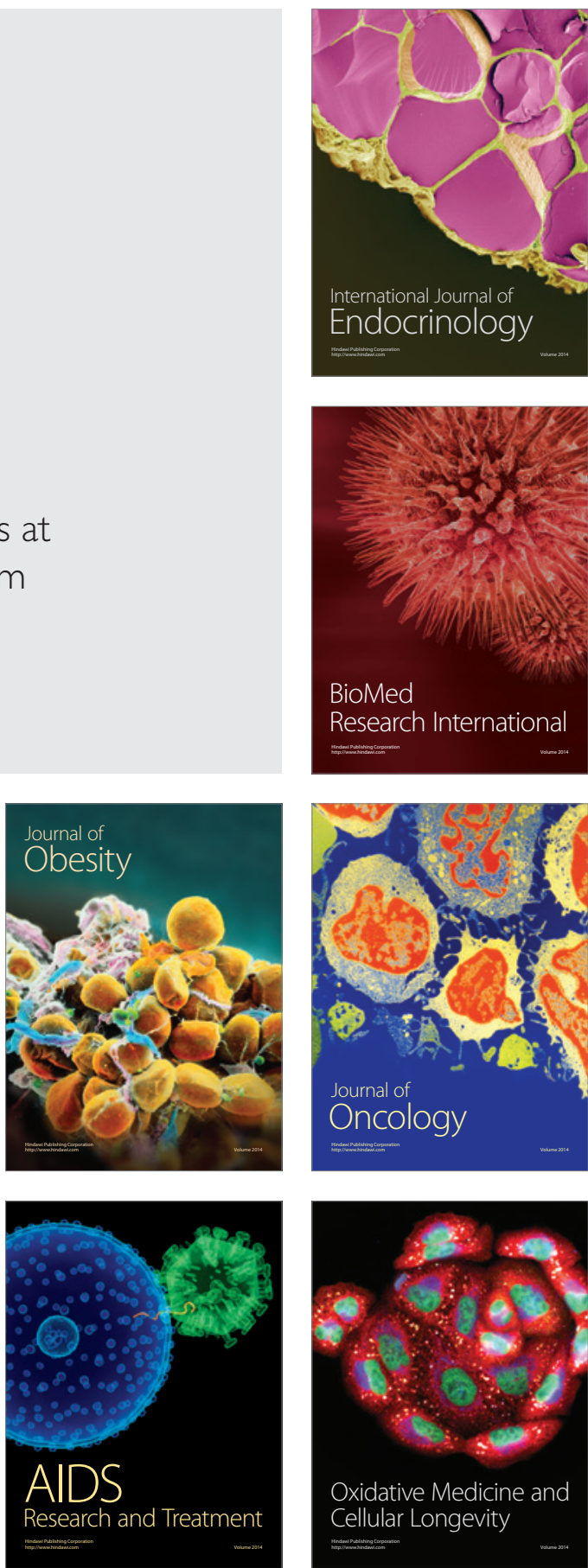